\title{
Retraction Note: Isolation and characterization of goat retinal microvascular endothelial cells
}

\author{
Ravinarayanan Haribalaganesh • Elayappan Banumathi • \\ Sardarpasha Sheikpranbabu • Venkataraman Deepak • Namagiri Sirishkumar • \\ Sangiliyandi Gurunathan
}

Published online: 25 October 2011

(C) The Society for In Vitro Biology 2011

\section{Retraction Note: In Vitro Cell.Dev.Biol.-Animal \\ DOI 10.1007/s11626-010-9292-4}

The paper, "Isolation and characterization of goat retinal microvascular endothelial cells," by Haribalaganesh Ravinarayanan, Banumathi Elayappan, Sheikpranbabu Sardarpasha, Deepak Venkataraman, Sirishkumar Namagiri, and Gurunathan Sangiliyandi has been retracted at the request of the Editors as it contains fraudulently manipulated data. Our investigation has found at least two instances of data misrepresentation in this paper. In figure $2 \mathrm{a}$, the $12 \mathrm{~h} / 10 \% \mathrm{FBS}$ and $24 \mathrm{~h} / 1 \% \mathrm{FBS}$ photomicrographs are identical as are the $24 \mathrm{~h} / 10 \% \mathrm{FBS}$ and $36 \mathrm{~h} / 10 \% \mathrm{FBS}$ photomicrographs. We have also found instances of image duplication in the $0 \mathrm{~h} / 1 \% \mathrm{FBS}, 0 \mathrm{~h} / 10 \% \mathrm{FBS}$, $12 \mathrm{~h} / 1 \% \mathrm{FBS}$ and $24 \mathrm{~h} / 1 \% \mathrm{FBS}$ photomicrographs. As such, this article represents a severe abuse of the scientific publishing system. The scientific community and the Editors take a very strong view on this matter, and apologies are offered to readers of the journal that this problem was not detected during the submission and review process.-The Editors

The online version of the original article can be found at http://dx.doi. org/10.1007/s11626-010-9292-4.

R. Haribalaganesh · E. Banumathi $\cdot$ S. Sheikpranbabu $\cdot$

V. Deepak $\cdot$ S. Gurunathan $(\bowtie)$

Department of Biotechnology, Division of Molecular and Cellular Biology, Kalasalingam University

(Kalasalingam Academy of Research and Education), Anand Nagar, Krishnankoil 626190 Tamilnadu, India

e-mail: lvsangs@yahoo.com

N. Sirishkumar

Department of Ophthalmology,

Meenakshi Mission Hospital and Research Center,

Madurai 625107 Tamilnadu, India 